\title{
Pengaruh Kepemimpinan dan Pelatihan \\ Terhadap Kinerja Karyawan Melalui Etos Kerja pada \\ PT. Bank Syariah Mandiri Kantor area Makassar
}

\section{Mashuri Yusuf Naim, Mursalim Umar Gani dan Rini Purnamasari \\ Pasca Sarjana Universitas Muslim Indonesia (UMI) Makassar \\ Institut Agama Islam Negeri (IAIN) Parepare}

\author{
yusuf.naim92@gmail.com \\ rinipurnamasari@iainpare.ac.id
}

\begin{abstract}
Abstrak
Tulisan ini bertujuan untuk menguji pengaruh kepemimpinan dan pelatihan terhadap kinerja karyawan melalui etos kerja pada PT Bank Syariah Mandiri kantor area Makassar. Data diperoleh dari karyawan di Bank Syariah Mandiri kantor area Makassar yang bersedia menjadi responden dengan melakukan penelitian langsung di lapangan dengan memberikan kuesioner pertanyaan kepada 60 responden. Metode analisis data yang digunakan yaitu analisis Structural Equation Model (SEM). Hasil penelitian menunjukkan bahwa: variabel kepemimpinan, epelatihan dan etos kerja berpengaruh positif dan signifikan terhadap kinerja karyawan. Variabel Kepemimpinan dan pelatihan berpengaruh positif dan signifikan terhadap etos kerja. Variabel Kepemimpinan dan pelatihan berpengaruh positif dan signifikan terhadap kinerja karyawan melalui etos kerja.
\end{abstract}

Kata Kunci: Kepemimpinan, Pelatihan, Etos Kerja

\section{Pendahuluan}

Sumber daya manusia yang berkualitas adalah sumber daya manusia yang memiliki pengetahuan, kemampuan, keterampilan dan sikap yang baik dalam bekerja. Oleh karena itu, organisasi perlu mengambil langkah agar dapat mengembangkan dan meningkatkan kualitas pegawai. Pegawai diharapkan selalu mengasah pengetahuan, keterampilan dan kemampuan agar lebih baik sesuai dengan tuntutan zaman serta dapat meningkatkan kinerja pegawai dalam organisasi tersebut. 
Kinerja pada dasarnya adalah apa yang dilakukan pegawai sehingga mempengaruhi seberapa banyak kontribusi mereka kepada instansi atau organisasi termasuk pelayanan kualitas yang disajikan. Organisasi dalam meningkatkan kinerja pegawai perlu adanya pengembangan sumber daya manusia yang tepat dengan lingkungan kerja yang mendukung. Faktor-faktor yang digunakan untuk meningkatkan kinerja pegawai diantaranya kemampuan individual (pengetahuan, keterampilan dan kemampuan), usaha yang dicurahkan, dan dukungan organisasional. Kinerja pegawai merupakan hasil olah pikir dan tenaga dari seorang pegawai terhadap pekerjaan yang dilakukan, dapat berwujud, dilihat, dihitung jumlahnya, akan tetapi dalam banyak hal hasil olah pikiran dan tenaga tidak dapat dihitung dan dilihat, seperti ide-ide dan inovasi dari pegawai dalam rangka meningkatkan kemajuan organisasi.

Dalam meningkatkan kinerja, etos kerja sering diartikan sebagai perilaku kerja yang etis menjadikan kebiasaan kerja yang berporoskan etika atau dengan nama lain yang lebih sederhana, etos kerja yaitu semua kebiasaan yang baik yang berlandaskan etika yang harus dilakukan ditempat kerja. Etos kerja dalam organisasi mencakup motivasi yang menggerakkan, karakteristik utama, spirit dasar, pikiran dasar, kode etik, kode moral, kode perilaku, sikap-sikap, aspirasi-aspirasi, keyakinan-keyakinan, prinsip-prinsip dan standar-standar yang menjadi dasar perilaku dan nilai-nilai yang diadopsi individu-individu manusia di dalam organisasi atau konteks sosialnya. ${ }^{1}$

Etos kerja adalah suatu pandangan dan sikap seseorang terhadap pekerjaan yang ditekuninya. ${ }^{2}$ Etos kerja yang dimiliki oleh seorang atau pegawai akan menjadi sumber motivasi bagi perbuatannya. Sondang, menjelaskan bahwa etos kerja merupakan norma-norma yang bersifat

1 Damayanti,2008. Faktor Penghambat Produktivitas Kerja, http://wordpress.com, diakses 25 Februari 2019

2 Ndraha, Taliziduhu. Pengantar Pengembangan Sumber Daya Manusia. Cetakan Pertama. (Jakarta: PT. Rineka Cipta. 2002), h. 80 
mengikat dan ditetapkan secara eksplisit serta praktik-praktik yang diterima dan diakui sebagai kebiasaan yang wajar untuk dipertahankan dan diterapkan dalam kehidupan karyawan para anggota organisasi. ${ }^{3}$

Untuk meningkatkan kinerja dan etos kerja, maka diperlukan kepemimpinan yang baik dan pelatihan yang dilaksanakan oleh perusahaan. Seoarang pemimpin dituntut agar memiliki kemampuan menggerakkan perusahaan dalam melaksanakan tugas sesuai prinsip-prinsipnya. Dipihak lain, kepemimpinan adalah suatu kemampuan mempengaruhi kelompok kearah pencapaian tujuan. Namun, kepemimpinan dalam sebuah lembaga yang efektif memberikan dasar dan menempatkan tujuan pada posisi penting dalam program pengembangan, meningkatkan produktivitas dan mengembangkan pendekatan-pendekatan kreatif untuk memperoleh hasil yang maksimal dari program lembaga tersebut.

Pemimpin yang efektif memerlukan manajemen dalam menyusun tujuan, sasaran, mengatur standar operasional, menciptakan lingkungan kerja yang produktif pada sebuah lembaga. Seiring perkembangan dunia perbankan yang berdampak pada eksistensi bank tersebut, maka muncul berbagai pemasalahan dalam pengelolaan lembaga. Permasalahanpermasalahan tersebut yaitu ketepatan dalam pengambilan keputusan, pendelegasian dan pembagian tugas, mengembangkan sikap demokrasi, visiner dan peduli terhadap pembaharuan.

Pelatihan pegawai merupakan kegiatan pengembangan sumber daya manusia untuk meningkatkan pengetahuan, kemampuan dan keterampilan, serta meningkatkan kinerja pegawai. Pendidikan dan pelatihan berupaya mengembangkan kemampuan intelektual dan kepribadian pegawai. Oleh karena itu setiap organisasi yang ingin berkembang harus benar-benar memperhatikan pendidikan dan pelatihan pegawai sehingga dapat berpengaruh terhadap peningkatan kinerja pegawai.

3 P. Siagian, Sondang.2002. Kepemimpinan Organisasi \& Perilaku Administrasi,. Jakarta: Penerbit Gunung Agung. Perbandingan)”, Religia, Vol. 13, No. 2, 239-254 
Salah satu kunci penting untuk menjaga kualitas kinerja Bank Syariah Mandiri (BSM) adalah mengembangkan dan mendidik karyawan secara berkesinambungan. BSM memiliki komitmen yang tinggi terhadap peningkatan kualitas sumber daya manusia (SDM). SDM yang unggul menjadi penopang utama untuk menjadi pemimpin pasar dan lokomotif pengembangan perbankan syariah di Indonesia. Untuk melahirkan SDM yang unggul, BSM menumbuhkembangkan budaya pembelajaran secara berkelanjutan, dan didukung fasilitas belajar terbaik. BSM telah menyediakan sarana peningkatan kualitas SDM melalui beragam fasilitas pendidikan dan pelatihan (Diklat), terdiri: Program Pelatihan Berbasis Kompetensi; ELearning; Learning Center.

Program diklat yang bertujuan untuk memenuhi kompetensi sesuai jabatan setiap pegawai.Program ini disusun berdasarkan Competency Based Human Resources Management (CBHRM) yang dikembangkan di internal BSM. Rincian program berbasis kompetensi ini meliputi:

1. Core Training yaitu diklat dasar yang wajib diikuti oleh seluruh pegawai BSM.

2. Functional Training yaitu diklat yang bertujuan meningkatkan kompetensi teknis sesuai dengan jabatan (job desk) pegawai.

3. Behaviour Training yaitu diklat yang bertujuan meningkatkan kompetensi perilaku pegawai pada level dan jabatan tertentu.

4. Managerial Training yaitu diklat yang bertujuan meningkatkan kompetensi manajerial dan leadership pegawai BSM yang menduduki jabatan struktural.

Sebagai Bank Syariah terbesar, PT Bank Syariah Mandiri terus berkomitmen untuk selalu melakukan penguatan daya saing perusahaan. Hal tersebut antara lain dilakukan melalui penguatan kompetensi usaha dan peningkatan layanan digital di 2019. Berbagai upaya penguatan kompetensi telah dilakukan melalui berbagai pelatihan khusus antara lain pelatihan kepemimpinan (leadership training) ke luar negeri baik dalam bentuk 
Sekolah Staf dan PimpinanBank, Management Development Program,maupun Graduate Development Program. Diantara pelatihan tersebut dilakukan melalui sinergi dengan Bank Mandiri selaku induk perusahaan. Di samping itu, peningkatan kompetensi juga dilakukan dengan cara menugaskan karyawan ke berbagai pelatihan diluar negeri baik di level Group Head, Department Head, maupun Officer. Selain peningkatan kompetensi melalui berbagai pelatihan, PT Bank Syariah Mandiri melalui Peningkatan Keunggulan Perusahaan Mandiri juga telah mengubah pola grading pegawai, pola kenaikan grade, dan apresiasi, sehingga mampu mendorong produktivitas pegawai dengan efektif. Dalam upayanya memberikan peningkatan layanan digital yang sangat dibutuhkan dalam peningkatan daya saing perusahaan, PT Bank Syariah Mandiri telah menghadirkan new mobile banking, dengan beragam fitur. Layanan digital baik untuk layanan transaksi perbankan dan juga telah dilengkapi dengan berbagai fitur layanan ibadah seperti wakaf, ZIS, waktu sholat, masjid terdekat dan arah kiblat. Selain peningkatan kualitas SDM dan layanan digital, PT Bank Syariah Mandiri juga terus meningkatkan penguatan dari sisi bisnis. Hal tersebut dilakukan dengan tetap fokus pada target market dan senantiasa menjalin sinergi dengan Mandiri Group.

\section{Kepemimpinan Melalui Pendidikan dan Pelatihan Kerja}

Kepemimpinan adalah suatu proses dimana individu mempengaruhi kelompok untuk mencapai tujuan umum. Pengertian ini dipertajam oleh Dubrin bahwa kepemimpinan itu adalah kemampuan untuk menanamkan keyakinandan memperoleh dukungan dari anggota organisasi untuk mencapai tujuan organisasi. Kepemimpinan itu ada pada diripemimpin/ manajer.Dari aspek karakteristik dibedakan antara karakteristik pemimpin (leader) dengan karkateristik manajer. Luthans menegaskan bahwa karakteristik pemimpin di Abad XXI adalah: Innovates (menciptakan sesuatu yang baru); An original (asli dari pemimpin); Develops (mengembangkan); 
Focuses on people (terkonsentrasi padamanusia); Inspires trust (menghidupkan rasa percaya); Longrange perspective (memiliki prespektif jangka panjang); Askswhat and why (ia menanyakan apa dan mengapa); Eye on the horizon (berpandangan sama pada sesamanya); Originates (memiliki keaslian); Challenges the Status quo (menentang kemapanan); Own person (mengakui tanggung jawab ada pada pemimpin); Does the right thing (mengerjakan yang benar).

Pemimpin memiliki karakteristik selalu memiliki upaya untuk menciptakan hal yang baru (selalu berinovasi).Gagasangagasanyang dimiliki oleh pemimpin merupakan gagasan sendiri tidak meniru ataupun menjiplak. Pemimpin selalu berupaya untuk mengembangkan apa yangia lakukan. Ia percaya pada bawahan, dan selalu menyalakan api kepercayaan pada anggota organisasi. Gagasannya memiliki prespektif jangka panjang. Ia bertanya pada bawahannya dengan pertanyaan apa danmengapa?.Ia menentang status quo, ia tidak puas dengan apa yang ada. Ia bertanggung jawab atas apa yang dilakukan oleh bawahannya, dan ia mengerjakan yang benar.

Perubahan lingkungan dan teknologi yang sangat cepat meningkatkan kompleksitas tantangan yang dihadapi oleh organisasi, hal ini memunculkan kebutuhan organisasi terhadap pemimpin yang dapat mengarahkan dan mengembangkan usaha-usaha karyawan dengan kekuasaan yang dimiliki untuk mencapai tujuan organisasi dalam membangun organisasi menuju high performance organization. Aprilita dalam penelitiannya mengemukakan, pemimpin sukses apabila pemimpin tersebut mampu menjadi pendorong bagi bawahannya dengan menciptakan budaya kerja dan suasana yang dapat memacu pertumbuhan dan perkembangan kinerja karyawannya, serta memiliki kemampuan untuk memberikan pengaruh positif bagi karyawannya untuk melakukan pekerjaan sesuai dengan arahan dan tujuan yang ingin dicapai. 
Menurut Griffin dan Ebert kepemimpinan (leadership) adalah proses memotivasi orang lain untuk mau bekerja dalam rangka mencapai tujuan yang telah ditetapkan. Lindsay dan Patrick dalam membahas "Mutu Total dan Pembangunan Organisasi" mengemukakan bahwa kepemimpinan adalah suatu upaya merealisasikan tujuan perusahaan dengan memadukan kebutuhan para individu untuk terus tumbuh berkembang dengan tujuan organisasi. Perlu diketahui bahwa para individu merupakan anggota dari perusahaan. Peterson at.all mengatakan bahwa kepemimpinan merupakan suatu kreasi yang berkaitan dengan pemahaman dan penyelesaian atas permasalahan internal dan eksternal organis.

Sumber Daya Manusia yang kompeten adalah sumber daya yang memiliki sifat kafa'ah / keahlian dalam bekerja, amanah / terpecaya dalam melaksanakan tugas, dan himmatul amal / memiliki perilaku kerja yang baik. Untuk menciptakan SDM yang sangat kompeten, diperlukan training yang berlandaskan pada tiga aspek, yaitu: (1) Syakhshiyyah Islamiyyah atau kepribadian diri Islamnya, (2) skill atau keahlian maupun keterampilannya, dan (3) kepemimpinan dan kerjasamanya dalam tim sebuah organisasi. Kualitas sumber daya manusia sangat berhubungan erat dengan pencapaian kerja tiap-tiap individu dalam setiap perusahaan atau organisasi, pencapaian etos kerja Islami sendiri dimana berorientasi pada motivasi ibadah sebagai pendorong utama merupakan salah satu bagian yang menunjukkan kualitas sumber daya manusia itu sendiri. ${ }^{4}$

Dalam kaitannya dengan lembaga keuangan syariah, Imam Ghazali menjelaskan bahwa sumber daya insani merupakan kontribusi dalam peningkatan market share perusahaan dalam semua aspek dan menjaganya

\footnotetext{
${ }^{4}$ Rahayu, F., dan Cahyono, H. 2018."Pengaruh Pelatihan dan Pengembangan Sumber Daya Manusia Terhadap Peningkatan Etos Kerja Islami Kary Bank Syariah Bukopin Cabang Darmo Surabaya".Jurnal Ekonomi Islam.Vol. 1, No.2.
} 
untuk tetap bertahan pada kondisi yang baik yaitu yang diinginkan perusahaan. ${ }^{5}$

Dalam upaya meningkatkan sumber daya aparatur setiap pekerjaan harus menghubungkan dengan pendidikan maupun pelatihan. Hasibuan menyatakan dalam tulisannya bahwa Pendidikan adalah sebuah proses untuk meningkatkan atau memperbaiki keahlian secara keseluruhan. Dengan begitu pegawai yang mendapatkan pendidikan secara berencana sesuai dengan prosedur cenderung lebih bekerja secara profesional jika dibandingkan dengan pegawai pada organisasi yang tidak melakukan pelatihan sebelumnya. Oleh karena itu pendidikan dianggap sangat penting dan mempunyai manfaat bukan karena tuntutan pekerjaan dan jabatan akibatnya dari perubahan situasi dan kondisi kerja, kemajuan teknologi yang semakin tahun semakin maju dan semakin ketat persaingannya didalam suatu organisasi atau lembaga.

Manullang menyatakan pendidikan dan pelatihan merupakan kebutuhan penting suatu pekerjaan yang bisa menentukan dan menghubungkan pengetahuan dengan keahlian berdasarkan kegiatan yang sebenarnya dilakukan pada pekerjaan. Pendidikan dan pelatihan pegawai merupakan kebutuhan suatu pekerjaan yang penting untuk memperbaiki pengetahuan dan kemahiran seseorang, sedangkan keahlian dan pengetahuan berdasarkan aktivitas kerja yang sesungguhnya terinci dan rutin supaya dapat menjalankan dan menyelesaikan pekerjaan yang sesuai dengan tugasnya. Hal ini sejalan dengan penelitian Arief Aliman, yang menemukan bahwa pendidikan memberikan efek yang positif terhadap kinerja.

\section{Pengertian Pelatihan}

Pelatihan pada prinsipnya merupakan upaya membekali seseorang dengan pengetahuan dan keterampilan serta attitude sehingga seseorang

${ }^{5}$ Hasan, F. A., dan Maulana, M. I. (2016). "Meningkatkan Kualitas Sumber Daya Insani di Lembaga Keuangan Syariah dalam Menghadapi Persaingan Global”.Sosio Didaktika: Social Science Education Journal, Vol. 3 (1): hal. 28-31 
memiliki kemampuan dalam melaksanakan tugas atau aktivitas keorganisasian sehari-hari. Dengan demikian melalui pengetahuan dan keterampilan serta attitude yang diperoleh melalui pelatihan tersebut, seorang pegawai atau anggota organisasi dapat lebih percaya diri didalam menghadapi persoalan yang dihadapi dalam tugasnya. Melalui program pelatihan diharapkan seluruh potensi yang dimiliki dapat ditingkatkan sesuai dengan keinginan organisasi atau setidaknya mendekati apa yang diharapkan oleh organisasi. Pelatihan biasanya dilaksanakan pada saat para pekerja memiliki keahlian yang kurang atau pada saat suatu organisasi mengubah suatu sistem dan perlu belajar tentang keahlian baru.

Veithzal Rivai menjelaskan, bagian pendidikan yang menyangkut proses belajar untuk memperoleh dan meningkatkan keterampilan diluar sistem pendidikan yang berlaku dalam waktu relatif singkat dengan metode yang lebih mengutamakan pada praktek dari pada teori. Adapun uraian lain dari Gary Dessler dalam Benyamin yaitu, memberikan keterampilan yang dibutuhkan bagi karyawan baru atau karyawan yang sudah ada untuk menyelenggarakan pekerjaannya. Berdasarkan beberapa pendapat para ahli mengenai pelatihan diatas, dapat disimpulkan bahwa pelatihan merupakan suatu proses pendidikan jangka pendek dimana karyawan mendapat tambahan kemampuan dan keterampilan kerja pegawai atau karyawan dalam menjalankan pekerjaannya agar dapat meningkatkan kemampuannya untuk mencapai tujuan perusahaan.

2. Faktor-Faktor Yang Mempengaruhi Pelatihan

Metode pelatihan terbaik tergantung dari berbagai faktor. Berdasarkan penjelasan Veithzal Rivai, dalam melakukan pelatihan ada beberapa faktor yang mempengaruhi yaitu instruktur, peserta, materi (bahan), metode, tujuan pelatihan, dan lingkungan yang menunjang. Faktor-faktor yang perlu dipertimbangkan dalam pelatihan yaitu :

a. Efektivitas biaya 
b. Materi program yang dibutuhkan

c. Prinsip-prinsip pembelajaran

d. Ketepatan dan kesesuaian fasilitas

e. Kemampuan dan preferensi peserta pelatihan

f. Kemampuan dan preferensi instruktur pelatihan

Mengingat ketatnya persaingan industri perbankan saat ini, maka PT Bank Syariah Mandiri (BSM) memiliki komitmen yang tinggi terhadap peningkatan kualitas Sumber Daya Manusia (SDM). Dengan SDM yang unggul diharapkan menjadi penopang utama untuk memimpin pasar dan lokomotif pengembangan perbankan syariah di Indonesia. Terkait pelatihan karyawan, PT Bank Syariah Mandiri dalam menghadapi berbagai macam persaingan baik dengan bank syariah maupun bank konvensional, telah memprogram pelatihan bagi karyawannya. PT Bank Syariah Mandiri telah menyediakan sarana untuk meningkatkan kualitas sumber daya manusia melalui beragam fasilitas pendidikan dan pelatihan (Diklat) yang terdiri dari program pelatihan berbasis kompetensi, E-Learning, dan Learning Center.

1) Pelatihan berbasis kompetensi yaitu, program pendidikan dan pelatihan (diklat) yang bertujuan untuk memenuhi kompetensi sesuai jabatan setiap pegawai. Program ini disusun berdasarkan Competency BasedHuman Resources Management (CBHRM) yang dikembangkan diinternal Bank Syariah Mandiri.

2) E-Learning, yaitu proses pembelajaran melalui bantuan teknologi informasi. E-Learning merupakan salah satu infrastruktur yang dapat mempercepat proses pengembangan pegawai karena dapat diakses melalui seluruh kantor cabang Bank Syariah Mandiri di seluruh Indonesia pada waktu yang tidak terbatas. E-Learning Bank Syariah Mandiri menyediakan ratusan materi pelatihan dan ribuan soal-soal test evaluasi dari berbagai topik pelatihan. 
3) Learning Centre, yaitu sebagai pusat pembelajaran class room training baik di Jakarta maupun Kantor Wilayah. LearningCentre Bank Syariah Mandiri berlokasi di Universitas Al-Azhar Lantai tujuh, Jakarta. Fasilitas yang disediakan meliputi ruang kelas,laboratorium mini bank dengan jaringan intranet dan E-Learning, ruang makan, musholla dan antor pengelola diklat. Bank Syariah Mandiri juga menyediakan laboratorium gadai emas untuk peningkatan keterampilan pegawai yang mengembangkan bisnis gadai emas, baik dari levelpelaksana sampai level manajerial.

Program pendidikan dan pelatihan (diklat) di PT Bank Syariah Mandiri berjalan melalui 3 metode delivery, yaitu E-Learning, Classroom Training, dan Blended E-Learning.

a. Untuk program pelatihan E-Learning, dimulai dari proses pendaftaran, pelatihan, test dan evaluasi sampai dengan penerbitan sertifikat pelatihan.

b. Untuk Classroom Training, proses pelatihan yang dilaksanakan di dalam kelas (di Learning Centre Bank Syariah Mandiri maupun di cabang koordinator) untuk meningkatkan skill pegawai.

c. Untuk program Blended Learning, proses pelatihan yang memadukan antara proses pembelajaran melalui E-Learning dan classroom. Pegawai terlebih dahulu belajar melalui E-Learning untuk meningkatkan pengetahuan. Setelah lulus pre-test di E-Learning, pegawai mengikuti classroom training guna meningkatkan skill dari pengetahuan yang telah didapat melalui E-Learning. Setelah mengikuti class room training karyawan akan mengikuti post test untuk evaluasi pelatihan. Dalam tes tersebut, apabila karyawan tidak dapat memenuhi standar nilai 80 maka, karyawan tersebut harus melakukan pelatihan ulang melalui E-Learning hingga memenuhi standar nilai yang ditetapkan. 


\section{Etos Kerja dan Kinerja Karyawan}

Dalam bahasa Inggris Etos dapat diterjemahkan menjadi beberapa pengertian antara lain 'starting point', 'to appear', 'disposition' hingga disimpulkan sebagai 'character'. Dalam bahasa Indonesia kita dapat menterjemahkannya sebagai 'sifat dasar', 'pemunculan' atau 'disposisi/watak'.

Dalam rumusan Jansen Sinamo, Etos Kerja adalah seperangkat perilaku positif yang berakar pada keyakinan fundamental yang disertai komitmen total pada paradigma kerja yang integral. Menurutnya, jika seseorang, suatu organisasi, atau suatu komunitas menganut paradigma kerja, mempercayai, dan berkomitmen pada paradigma kerja tersebut, semua itu akan melahirkan sikap dan perilaku kerja mereka yang khas. Itulah yang akan menjadi Etos Kerja dan budaya. Sinamo memandang bahwa Etos Kerja merupakan fondasi dari sukses yang sejati dan otentik.Pandangan ini dipengaruhi oleh kajiannya terhadap studi-studi sosiologi sejak zaman Max Weber di awal abad ke-20 dan penulisan-penulisan manajemen dua puluh tahun belakangan ini yang semuanya bermuara pada satu kesimpulan utama; bahwa keberhasilan di berbagai wilayah kehidupan ditentukan oleh perilaku manusia, terutama perilaku kerja.Sebagian orang menyebut perilaku kerja ini sebagai motivasi, kebiasaan (habit) dan budaya kerja. Sinamo lebih memilih menggunakan istilah etos karena menemukan bahwa kata etos mengandung pengertian tidak saja sebagai perilaku khas dari sebuah organisasi atau komunitas tetapi juga mencakup motivasi yang menggerakkan mereka, karakteristik utama, spiritdasar, pikiran dasar, kode etik, kode moral, kode perilaku, sikap-sikap, aspirasi-aspirasi, keyakinan-keyakinan, prinsip-prinsip, dan standar-standar. ${ }^{6}$

Sumber daya manusia merupakan aset vital organisasi karena perannya dalam implementasi strategi sangat penting yaitu sebagai subjek

6 Sinamo, Jansen, Etos Kerja Profesional di Era Digital Global, (Jakarta: Institut Dharma Mahardika, 2002), h. 62 
pelaksana dari strategi organisasi. Sumber daya manusia ini adalah orangorang yang ada di dalam organisasi yang berkaitan langsung dengan pekerjaannya di dalam organisasi. Secara etimologi, kinerja berasal dari kata prestasi kerja (performance).

Menurut Prawirosentono kinerja adalah hasil kerja yang dapat dicapai oleh seseorang atau sekelompok orang dalam organisasi, sesuai dengan wewenang dan tanggung jawab masing-masing dalam rangka upaya mencapai tujuan organisasi secara legal, tidak melanggar hukum dan sesuai dengan moral dan etika. Kemudian menurut Curtis, "performance is behavior that has been evaluated in term of its contribution to the goals of theorganization". Kinerja adalah perilaku yang telah dievaluasi kontribusinya untuk pencapaian tujuan organisasi.

\section{Pengaruh Kepemimpinan Terhadap Kinerja Karyawan}

Hasil uji hipotesis menunjukkan bahwa variabel kepemimpinan berpengaruh positif dan signifikan terhadap kinerja karyawan. Semakin baik kepemimpinan yang diterapkan oleh pimpinan, maka akan membuat kinerja karyawan semakin meningkat. Dalam prakteknya kepemimpinan ini diwarnai oleh usaha mewujudkan hubungan manusiawiyang efektif, dengan prinsip saling memperlakukan sebagai subyek. Pemimpin memandang anggota organisasinya sebagai individu yang harus dihormati, dihargai dan diakui hak dan kewajibannya. Dengan kata lain setiap individu diterima eksistensinya dengan kepribadian masing-masing, sebagaimana diri pemimpin sendiri. Oleh karena itu pimpinan PT Bank Mandiri Syariah cabang Makassar dalam menjalankan kepemimpinan dengan baik, dengan menjalankan dasar-dasar kepemimpinan islam yaitu bertaqwa kepada Allah SWT, Amanah, adil, bertanggung jawab, melakukan musyawarah dan istiqarah, sehingga setiap kemauan, kehendak, kemampuan, buah pikiran, gagasan, pendapat, minat dan perhatian dan lain-lain, yang berbeda-beda 
antar individu, selalu dihargai dan disalurkan untuk kepentingan bersama, sehingga akan meningkatkan kinerja karyawan.

Penelitian ini sejalan dengan penelitian yang dilakukan oleh Sunarji Harahap yang menyatakan bahwa Kepemimpinan Islami yang berpengaruh signifikan positif terhadap kinerja karyawan. Penelitian ini juga didukung oleh penelitian Amelia yang menyatakan bahwa kepemimpinan berpengaruh positif dan signifikan terhadap kinerja karyawan Bank Syariah Mandiri.

Penelitian ini juga sejalan dengan penelitian Donni Juni Priansa Kepemimpinan berpengaruh positif dan signifikan terhadap kinerja karyawan Bank Syariah Mandiri. Dengan demikian, BSM perlu meningkatkan kualitas kepemimpinan visioner dan etos kerja pegawai karena terbukti mempengaruhi kinerja pegawai.

\section{Pengaruh Pelatihan Terhadap Kinerja karyawan}

Hasil uji hipotesis menunjukkan bahwa variabelpelatihan berpengaruh positif dan signifikan terhadap kinerja karyawan. Semakin baik pelatihan maka akan membuat kinerja karyawan semakin meningkat. Pelatihan dan kinerja yang baik dapat juga menunjang keberhasilan suatu perusahaan dalam mencapai tujuannya. Sebab dengan adanya pelatihan dan kinerja yang baik akan menciptakan tingkat produktifitas kerja yang tinggi sehingga dapat menunjang keberhasilan perusahaan. Sebaliknya jika tingkat kinerja karyawan menurun, maka akan menghambat perusahaan tersebut dalam mencapai tujuannya.

Pelatihan dan kinerja yang baik dapat juga menunjang keberasilan suatu perusahaan dalam mencapai tujuannya. Sebab dengan adanya pelatihan dan kinerja yang baik akan menciptakan tingkat produktifitas kerja yang tinggi sehingga dapat menunjang keberhasilan perusahaan. Sebaliknya jika tingkat kinerja karyawan menurun, maka akan menghambat perusahaan tersebut dalam mencapai tujuannya 
Penelitian ini sejalan dengan penelitian yang dilakukan oleh Arif Aliman yang menyatakan bahwa pelatihan berpengaruh positif dan signifikan terhadap kinerja karyawan. ${ }^{7}$ Penelitian yang dilakukan oleh Muhammad Saleem, menunjukkan bahwa ada pengaruh antara pelatihan dan pengembangan terhadap kinerja pegawai. ${ }^{8}$

\section{Pengaruh Etos kerja Terhadap Kinerja Karyawan}

Hasil uji hipotesis menunjukkan bahwa variabeletos kerja berpengaruh positif dan signifikan terhadap kinerja karyawan. Semakin baik etos kerja yang dimiliki oleh karyawan, maka kinerja karyawan semakin meningkat. Etos kerja dan kinerja yang baik dapat juga menunjang keberasilan suatu organisasi dalam mencapai tujuannya. Sebab dengan adanya Etos kerja dan kinerja yang baik akan menciptakan tingkat produktifitas kerja yang tinggi sehingga dapat menunjang keberhasilan organisasi. Sebaliknya jika tingkat kepuasan kerja menurun, maka akan menghambat perusahaan tersebut dalam mencapai tujuannya.

Etos kerja yang dimiliki oleh seseorang atau kelompok masyarakat, akan menjadi sumber motivasi bagi perbuatannya. Apabila dikaitkan dengan situasi kehidupan manusia yang sedang "membangun", maka etos kerja yang tinggi akan dijadikan sebagai prasyaraat yang mutlak, yang harus ditumbuhkan dalam kehidupan itu.

Karena hal itu akan membuka pandangan dan sikap kepada manusianya untuk menilai tinggi terhadap kerja keras dan sungguh-sungguh, sehingga dapat mengikis sikap kerja yang asal-asalan, tidak berorientasi terhadap mutu atau kualitas yang semestinya.

${ }^{7}$ Arief Aliman. 2017.Education and Training in Enhancing Performance of Indonesia Port Corporation Employees. International Journal of Managerial Studies and Research (IJMSR) Volume 5, Issue 1, January 2017, PP 24-27 ISSN 2349-0330 (Print) \& ISSN 2349-0349 (Online) / 2349-0349.0501006 www. arc journals.org.

8 Muhammad Saleem at.al, (2018). Attitude and Perception of Employees towards Islamic Banking. IOSR Journal of Business and Management (IOSR-JBM) e-ISSN: 2278-487X, $p$ ISSN: 2319-7668. Volume 20, Issue 8. Ver. VI (August. 2018), PP 73-90 www.iosrjournals.org 
Penelitian ini juga sejalan dengan penelitian Donni Juni Priansa Etos Kerja berpengaruh positif dan signifikan terhadap kinerja karyawan Bank Syariah Mandiri. Dengan demikian, BSM perlu meningkatkan kualitas kepemimpinan visioner dan etos kerja pegawai karena terbukti mempengaruhi kinerja pegawai.

\section{Pengaruh Kepemimpinan Terhadap Etos Kerja}

Hasil uji hipotesis menunjukkan bahwa variabel kepemimpinan berpengaruh positif dan signifikan terhadap etos kerja. Semakin baik kepemimpinan yang diterapkan oleh pimpinan, maka akan membuat etos kerja semakin meningkat. Peranan pemimpin dalam pandangan kepemimpinan islam merupakan suatu penjelasan bahwa pemimpin yang membimbing atau memotivasi bawahan mereka ke arah tujuan yang telah ditetapkan dengan memperjelas peran dan tuntutan tugas, sehingga ia akan bekerja dengan giat.

Pimpinan Bank Syariah Mandiri dalam menjalankan kepemimpinan dengan baik, dengan menjalankan dasar-dasar kepemimpinan yaitu bertaqwa kepada Allah SWT, Amanah, adil, bertanggung jawab, melakukan musyawarah dan istiqarah, sehingga setiap kemauan, kehendak, kemampuan, buah pikiran, gagasan, pendapat, minat dan perhatian dan lainlain, yang berbeda-beda antar individu, selalu dihargai dan disalurkan untuk kepentingan bersama, sehingga karyawan akan termotivasi dalam bekerja.

Penelitian ini sejalan dengan penelitian yang dilakukan oleh Aziz dan Shofawati yang menyatakan bahwa kepemimpinan Islami berpengaruh signifikan terhadap variabel motivasi kerja Islami. Penerapan kepemimpinan Islami oleh para pengusaha sudah sesuai dengan keyakinan karyawan dan berjalan dengan baik, dapat dinilai sudah optimal dan kepemimpinan yang diterapkan sudah selaras dengan ajaran Islam. Penelitian ini juga sejalan dengan penelitian yang dilakukan oleh Fahrullah yang menyatakan bahwa kepemimpinan islam mempengaruhi motivasi karyawan di rumah sakit Islam. 
Penelitian ini sejalan dengan penelitian yang dilakukan oleh Sunarji Harahap yang menyatakan bahwa Kepemimpinan Islami yang berpengaruh signifikan positif terhadap kinerja karyawan. Penelitian ini juga didukung oleh penelitian Amelia yang menyatakan bahwa kepemimpinan berpengaruh positif dan signifikan terhadap kinerja karyawan Bank Syariah Mandiri.

Penelitian ini juga sejalan dengan penelitian Donni Juni Priansa Kepemimpinan berpengaruh positif dan signifikan terhadap kinerja karyawan Bank Syariah Mandiri. Dengan demikian, BSM perlu meningkatkan kualitas kepemimpinan visioner dan etos kerja pegawai karena terbukti mempengaruhi kinerja pegawai. ${ }^{9}$

\section{Pengaruh Pelatihan Terhadap Etos Kerja}

Hasil uji hipotesis menunjukkan bahwa variabelpelatihan berpengaruh positif dan signifikan terhadap etos kerja. Semakin baik pelatihan maka akan membuat etos kerja semakin meningkat. Pelatihan dan etos kerja yang baik dapat juga menunjang keberhasilan suatu perusahaan dalam mencapai tujuannya. Sebab dengan adanya pelatihan dan etos kerja yang baik akan menciptakan tingkat produktifitas kerja yang tinggi sehingga dapat menunjang keberhasilan perusahaan. Sebaliknya jika etos kerja karyawan menurun, maka akan menghambat perusahaan tersebut dalam mencapai tujuannya. Kemampuan juga merupakan dimensi perilaku keahlian atau keunggulan seseorang yang mempunyai pengetahuan, keterampilan dan kemampuan sikap dalam menyelesaikan suatu permasalahan. Kemampuan dalam organisasi sangat diperlukan terutama untuk menjawab tuntutan organisasi, dimana adanya perubahan yang sangat cepat, perkembangan masalah yang semakin kompleks dan dinamis, serta ketidakpastian masa depan dalam tatanan kehidupan masyarakat.

Penelitian ini sejalan dengan penelitian yang dilakukan oleh Arif Aliman yang menyatakan bahwa pelatihan berpengaruh positif dan signifikan

9 Donni Juni Priansa (2015). Pengaruh Kepemimpinan Visioner Dan Etos Kerja Terhadap Kinerja Pegawai Bank Syariah Mandiri. Ecodemica . Vol III . No. 1 April 2015 
terhadap kinerja karyawan. ${ }^{10}$ Penelitian yang dilakukan oleh Muhammad Saleem, menunjukkan bahwa ada pengaruh antara pelatihan dan pengembangan terhadap kinerja pegawai. ${ }^{11}$

\section{Pengaruh Kepemimpinan Terhadap Kinerja Karyawan Melalui Etos Kerja}

Hasil uji hipotesis menunjukkan bahwa variabel kepemimpinan berpengaruh positif dan signifikan terhadap kinerja karyawan melalui etos kerja. Semakin baik kepemimpinan yang diterapkan oleh pimpinan, maka akan membuat etos kerja islam meningkat, sehingga akan berdampak pada peningkatan kinerja karyawan. Peranan pemimpin dalam pandangan kepemimpinan islam merupakan suatu penjelasan bahwa pemimpin yang membimbing atau memotivasi bawahan mereka ke arah tujuan yang telah ditetapkan dengan memperjelas peran dan tuntutan tugas, sehingga karyawan dalam menjalankan tugasnya dapat menyelesaikannya dengan tepat waktu dan sebaik mungkin.

Penelitian ini sejalan dengan penelitian yang dilakukan oleh Sunarji Harahap yang menyatakan bahwa Kepemimpinan Islami yang berpengaruh signifikan positif terhadap kinerja karyawan. ${ }^{12}$ Penelitian ini juga didukung oleh penelitian Amelia yang menyatakan bahwa kepemimpinan berpengaruh positif dan signifikan terhadap kinerja karyawan Bank Syariah Mandiri. ${ }^{13}$

Penelitian ini juga sejalan dengan penelitian Donni Juni Priansa Kepemimpinan berpengaruh positif dan signifikan terhadap kinerja

${ }^{10}$ Arief Aliman. 2017.Education and Training in Enhancing Performance of Indonesia Port Corporation Employees. International Journal of Managerial Studies and Research (IJMSR) Volume 5, Issue 1, January 2017, PP 24-27 ISSN 2349-0330 (Print) \& ISSN 2349-0349 (Online) / 2349-0349.0501006 www. arc journals.org.

11Muhammad Saleem at.al, (2018). Attitude and Perception of Employees towards Islamic Banking. IOSR Journal of Business and Management (IOSR-JBM) e-ISSN: 2278-487X, $p$ ISSN: 2319-7668. Volume 20, Issue 8. Ver. VI (August. 2018), PP 73-90 www.iosrjournals.org

12 Sunarji Harahap (2016). Pengaruh Kepemimpinan Islami dan Motivasi Kerja Terhadap Kinerja Karyawan Pada PT. Bank Syariah Mandiri, Tbk Kantor Cabang Pembantu Sukaramai Medan. Human falah: volume 3. No. 2 juli - desember 2016

${ }^{13}$ Amelia. 2014. Pengaruh Kepemimpinan dan Motivasi terhadap Kinerja Karyawan Bank Syariah Mandiri (BSM) PO, Tangerang - BSD. Jurnal Ilmiah FE-UII Jogjakarta. 
karyawan Bank Syariah Mandiri. Dengan demikian, BSM perlu meningkatkan kualitas kepemimpinan visioner dan etos kerja pegawai karena terbukti mempengaruhi kinerja pegawai. ${ }^{14}$

\section{Penutup}

Pada dasarnya kinerja merupakan suatu tingkat dimana para karyawan mencapai persyaratan-persyaratan pekerjaan. Jika pelaksanaan pekerjaan telah sesuai atau bahkan melebihi uraian pekerjaan, hal ini berarti pekerjaan tersebut berhasil dikerjakan dengan baik, begitu pula sebaliknya. Melalui pelatihan, para karyawan akan mengetahui sampai dimana dan bagaimana prestasi kerjanya dinilai oleh atasan. Kelebihan dan kekurangan yang terjadi akan menjadi suatu kemampuan bagi perkembangan mereka di masa yang akan datang.

Semakin baik pelatihan maka akan membuat etos kerja semakin meningkat sehingga akan berdampak pada peningkatan kinerja karyawan. Pelatihan dan etos kerja yang baik dapat juga menunjang keberhasilan suatu perusahaan dalam mencapai tujuannya. Sebab dengan adanya pelatihan dan etos kerja yang baik akan menciptakan tingkat produktifitas kerja yang tinggi sehingga dapat menunjang keberhasilan perusahaan. Sebaliknya jika etos kerja karyawan menurun, maka akan menghambat perusahaan tersebut dalam mencapai tujuannya. Kemampuan juga merupakan dimensi perilaku keahlian atau keunggulan seseorang yang mempunyai pengetahuan, keterampilan dan kemampuan sikap dalam menyelesaikan suatu permasalahan. Kemampuan dalam organisasi sangat diperlukan terutama untuk menjawab tuntutan organisasi, dimana adanya perubahan yang sangat cepat, perkembangan masalah yang semakin kompleks dan dinamis, serta ketidakpastian masa depan dalam tatanan kehidupan masyarakat.

14 Donni Juni Priansa (2015). Pengaruh Kepemimpinan Visioner Dan Etos Kerja Terhadap Kinerja Pegawai Bank Syariah Mandiri. Ecodemica . Vol III . No. 1 April 2015 


\section{Daftar Pustaka}

Amelia. 2014. Pengaruh Kepemimpinan dan Motivasi terhadap Kinerja Karyawan Bank Syariah Mandiri (BSM) PO, Tangerang - BSD. Jurnal Ilmiah FE-UII Jogjakarta.

Anoraga, Pandji. 1992. Psikologi Kepemimpinan. Jakarta: Rineka Cipta.

Anwar Prabu Mangkunegara. 2005. Sumber Daya Manusia perusahaan. Remaja. Rosdakarya: Bandung.

Arief Aliman. 2017.Education and Training in Enhancing Performance of Indonesia Port Corporation Employees. International Journal of Managerial Studies and Research (IJMSR) Volume 5, Issue 1, January 2017, PP 24-27 ISSN 2349-0330 (Print) \& ISSN 2349-0349 (Online) / 2349-0349.0501006 www. arc journals.org.

Aziz, Abdul El-Qussy. Pokok-pokok Kesehatan Mental. terj. Dr. Zakiah. Daradjat. Jakarta: Bulan Bintang. 1974.

Bennis, W. \&Nanus, B. (2006) Leaders Strategi Untuk Mengemban Tanggung Jawab,. Jakarta: PT. Buana Ilmu Populer.

Caniago S.A., 2010, “Kepemimpinan Islam dan Konvensional (sebagai Studi

Daswati. 2012. Implementasi Peran Kepemimpinan dengan Gaya Kepemimpinan Menuju Kesuksesan Organisasi. Jurnal Akademika Fisip Unpad, 4(1), 783-798.

Donni Juni Priansa (2015).Pengaruh Kepemimpinan Visioner Dan Etos Kerja Terhadap Kinerja Pegawai Bank Syariah Mandiri.E c o d e m i c a . V o l I I I . N o. 1 A p ril 2015.

Geertz, Clifford. 1996. Religion as a Cultural System In Anthropological Approaches to the Study of Religion Ed Michael Bonton. London: TavistockPublications.

Hasan, F. A., dan Maulana, M. I. (2016). "Meningkatkan Kualitas Sumber Daya Insani di Lembaga Keuangan Syariah dalam Menghadapi Persaingan Global".Sosio Didaktika: Social Science Education Journal, $\quad$ Vol. 3 (1): hal. 28-31

Hasibuan, Malayu S.P. 2009. Manajemen Sumber Daya Manusia (Edisi revisi cetakan ke tiga belas). Jakarta: PT Bumi Aksara. 
Hasibuan, Malayu S.P. 2009. Manajemen: Dasar, Pengertian, dan Masalah. Edisi Revisi. Jakarta : Bumi Aksara.

Hendricks, G., and Ludeman, K. 2002. The Corporate Mystic. Penerbit Kaifa. Bandung.

Hill. Tosi., Caroll, SJ, 1997. Ogansational Theory and Management : A Macro Approach, John Willey and Sons Inc, New York.

Jansen. (2011). 8 Etos Kerja Profesional. Jakarta: Institut Dharma.

Muhammad Saleem at.al, (2018). Attitude and Perception of Employees towards Islamic Banking. IOSR Journal of Business and Management (IOSR-JBM) e-ISSN: 2278-487X, p-ISSN: 2319-7668. Volume 20, Issue 8. Ver. VI (August. 2018), PP 73-90 www.iosrjournals.org

Ndraha, Taliziduhu, 1999. Pengantar Teori Pengembangan Sumber daya. Manusia, Rineka Cipta, Jakarta.

Nurcholis Madjid (1995). Islam Kemoderanan dan Keindonesia. Mizan bandung.

Nurdin, Khaeruddin Yusuf (2014).Knowledge Management Lifecycle Model in Islamic Banks. International Journal of Information Studies Volume 10 Number 2 April 2018.

P. Siagian, Sondang.2002. Kepemimpinan Organisasi \& Perilaku Administrasi,. Jakarta: Penerbit Gunung Agung. Perbandingan)", Religia, Vol. 13, No. 2, 239-254.

Percy, Ian. 2003. Going Deep. Exploring Spirituality in Life and Leadership. Arizona: Inspired Production Press.

Prasetyo A., 2015, Pengaruh Kepemimpinan Islami dan Kompensasi Finansial terhadap Komitmen Organisasi dan Etos Kerja Islami serta Kinerja Karyawan pada Unit Usaha di Pondok Pesantren Jawa Timur, Disertasi, Unair, Surabaya.

Rahayu, F., dan Cahyono, H. 2018."Pengaruh Pelatihan dan Pengembangan Sumber Daya Manusia Terhadap Peningkatan Etos Kerja Islami Kary Bank Syariah Bukopin Cabang Darmo Surabaya".Jurnal Ekonomi Islam.Vol. 1, No.2.

Sabirin (2018).Analisa kinerja perbankan syariah di indonesia dengan menggunakan pendekatan islamicity performance index dan islamic 
corporate governance. Al-Maslahah - Volume 14 Nomor 2 Oktober 2018.

Simanjuntak, Payaman J. Edisi: ke-3 Penerbit: Depok: Lembaga Penerbit FEUI

Sulistyo (2009) Pengaruh Penelitian Emotional and Spiritual Quotient (ESQ) terhadap Komitmen Organisasi dan Etos Kerja (Studi Kasus Pelatihan ESQ PT. Indomobil Jakarta). Masters thesis, Universitas Terbuka.

Sunarji Harahap (2016). Pengaruh Kepemimpinan Islami dan Motivasi Kerja Terhadap Kinerja Karyawan Pada PT. Bank Syariah Mandiri, Tbk Kantor Cabang Pembantu Sukaramai Medan. Human falah: volume 3. No. 2 juli - desember 2016.

Supriyono, Widya Eka Larasati, and Ahmad Tibrizi Soni (2018).The Comparative Performance of Mandiri Syariah Bank and Maybank Berhad with the Concept of Maqashid Syariat. ICIFEB International Conference on Islamic Finance, Economics and BusinessVolume 2018.Sciences, pages 389-410. DOI 10.18502/kss.v3i8.2523.

Sureskiarti, Enok. (2015). Pengaruh Spiritual Leadership terhadap Kinerja Perawat dalam Melaksanakan Asuhan Keperawatan di RSUD Dr. H. Soewondo Kendal. Tesis, Program Studi Magister Keperawatan Fakultas Kedokteran Universitas Diponegoro, Semarang.

Sutono dan Fuad Ali Budiman. 2009. "Pengaruh Kepemimpinan Dan Etos Kerja Islami Terhadap Kinerja Karyawan Di Koperasi Jasa Keuangan Syari'ah Baitul Maal Wat Tamwil Di Kecamatan Rembang". Jurnal Analisis Manajemen. Vol. 4. No. 1. Hal. 11 - 28. Universitas Muria. Kudus.

Waqar Younas at.al, (2018). The Impact of Training and Development on Employee Performance:IOSR Journal of Business and Management (IOSR-JBM) e-ISSN: 2278-487X, p-ISSN: 2319-7668. Volume 20, Issue 7. Ver. IV(July. 2018), PP 20-23 www.iosrjournals.org.

Yusanto, M.I. dan Widjajakusuma M.K., 2003, Manajemen Strategi Perspektif. Syari'ah, Penerbit Khairul Bayaan, Jakarta. 